\title{
KUIDAS ME MÕISTAME MÕISTEID?
}

\section{Ene Vainik, Toomas Kirt}

\begin{abstract}
Ülevaade. Artiklis antakse ülevaade erinevatest teoreetilistest lähenemistest mõistete olemusele ning nende vastasmõjust lingvistilise semantikaga. Käsitlemist leiavad klassikaline, prototüübi ja nn teooria teooria, lisaks võrgumudel, ruumiline, dünaamiline ja evolutsiooniline lähenemine. Ühe ja ainsa õige mõisteteooria väljaselgitamise asemel jõutakse järeldusele, et erinevad teoreetilised lähenemised on mõistete juures tähtsustanud eri aspekte olenevalt seatud eesmärgist. Artiklis näidatakse mitmesuguste lingvistikas käibel olevate semantiliste esituste seost vastavate mõisteteooriatega. ${ }^{*}$
\end{abstract}

Võtmesõnad: lingvistika, semantika, epistemoloogia, kognitiivteadus

\section{Sissejuhatus}

Õpetlaste arutelu mõistete olemuse üle on saanud alguse muistsest Kreekast ja kestab tänapäevani, ühtne arusaam mõistete olemusest aga puudub tänini. ${ }^{1}$ Kui varem kuulusid mõisted abstraktse mõtlemise vormidena pigem loogika ja filosoofia ${ }^{2}$ pärusmaale siis tänapäeval on mõiste korraga paljude distsipliinide huviorbiidis. Nüüd tunnevad mõiste vastu huvi ka (neuro)psühholoogia, lingvistika, informaatika, matemaatika ja loomulikult eelkõige kognitiivteadus (ingl cognitive science) kui interdistsiplinaarne uurimisala, mis seab tunnetusprotsesside seaduspärasuste avastamise ja kirjeldamise oma esmaseks uurimisülesandeks.

Lingviste sunnib mõiste olemuse üle mõtisklema ühest küljest teoreetiline huvi ning soov mõista inimkeele aluseks olevaid tunnetusmehhanisme; teisest küljest on vajadus aga ka puhtpraktiline. Näiteks terminitöös on tarvis seada kindel termin vastavusse kindla mõistega ja tagada terminitõlgete adekvaatsus tähistatava sisu alusel (vt nt Tavast 2004). Mõistepõhiselt käib ka tesaurusetüüpi sõnastike 3 ning elektroonsete ressursside, nagu WordNet, koostamine (Fellbaum 1999: 7). Semantilise komponendi kirjeldusteta ei pääseta ka tehisintellektis ja

\footnotetext{
Artikkel on valminud ETF-i grandi nr 7149 toel.

1 On tunnuslik, et püüd mõistest teadaolevat kokku võtta on päädinud mitte integreeritud vastusena küsimusele mis on mõiste? vaid asjassepuutuvate olulisemate kirjutiste mahuka kollektsioonina (vt Laurence, Margolis 1999).

2 Filosoofidest on mõistete üle arutlenud nt Platon, Aristoteles, Kant, Locke.

3 Sedalaadi töö pioneeriks eesti keele osas on A. Saareste "Eesti keele mõisteline sõnaraamat" (1958).
} 
keele modelleerimises. Mõiste ja tähenduse vahekorra osas aga üksmeel puudub: mõned autorid samastavad mõiste ja leksikaalse tähenduse (nt Cruse 2000), mõned peavad mõistet tähendusest avaramaks (nt Aitchison 2003), mõned räägivad mõiste tähendusest (Osgood jt 1975), mõned keeleüksuste mõistelisest tähendusest (Leech 1990 [1974]); kognitiivse lingvistika paradigmas tuuakse tähenduse avamiseks sisse mõistestamine (ingl conceptualisation) (Langacker 1987, 2002) jne.

Üldise arusaama kohaselt on nn leksikaalsed mõisted vastavuses sõnade ehk nende sümboolse esitusega (vt Laurence, Margolis 1999). Iga kord, kui me millegi kirjeldamiseks või määratlemiseks kasutame sõnu, toetume ka mõistetele. Paradoks on selles, et mõisteid defineerides oleme olukorras, kus kasutame ühtede sümbolite sisu edasiandmiseks teisi sümboleid. Tekib suletud süsteem ning küsimus, kuidas siiski sõnad kui mõiste sümbolid tähenduse omandavad, jääb vastuseta (Harnad 1999).

Sõnade ja mõistete vahelise seose uurimist on peetud lausa mädasooks - alaks, mis on täis keerukust ja võhiklikkust (Aitchison 2003: 43). Ka käesoleva artikli maht ei luba meil üritada avada mõiste erinevate mõistmisviiside ja mõiste ning tähenduse vahekorra kogu sügavust ja mitmepalgelisust. Kuivõrd on ilmne, et keelel (sõnadel) on mõistete mõistmises täita oluline roll, seame järgnevas eesmärgiks tutvustada erinevaid mõiste mõistmise viise ja nende vastasmõju lingvistilise semantikaga. Tulemusena peaks lugeja suutma orienteeruda erinevate lähenemisviiside rägastikus ja saama ülevaate sellest, kuhu ollakse tänapäeval mõistete olemuse seletamisel jõutud.

\section{Naiivne arusaam}

Kõige igapäevasemas mõttes tuleb mõiste mõiste käibele praktilisest vajadusest võtta kuidagi kokku sõnadetagune reaalsus (ld conceptum < concipere $=$ com 'kokku' + capere 'võtma'). Näiteks ühiskonna reguleerimisel õigusaktidega on ülioluline kokku leppida, et sõnu kasutataks järjepidevalt samade reaalsuskogumite tähistamiseks. Mõistete täpne maht ja kirjeldamine on väga oluline ka teaduses. Mistahes teadusliku käsitluse juurde kuulub selle põhimõistete määratlemine ja defineerimine. Seega oleks mõistete üks aspekte justkui nende piiritletus ja defineeritavus. Neilt eeldatakse ka vähemalt mõningat püsivust ja mentaalset manipuleeritavust, mis panebki meid mõistetest tavaliselt mõtlema kui iseseisvatest entiteetidest või asjadest.

Kuigi teadaolevalt ei ole neid asju seni keegi oma silmaga näinud, ${ }^{4}$ ei näi see tekitavat kahtlusi nende olemasolus. Me oleme rahul sellega, et mõisted toimetavad omasoodu, mõjutades seda, kuidas me asjadest aru saame. Kui me igapäevaselt mõtleme, arutleme, järeldame, aga ka unistame ja fantaseerime ning oma kaaslastega seda kõike jagame, siis ise sellest teadlikud olemata toetume paljudele ühistele mõistetele. Mõistete jagatus, kollektiivsus tagab selle, et me suudame teha end arusaadavaks teistele ning mõista teiste poolt väljendatut. Keele õppimisega paralleelselt me omandame ka vastavas kultuuris käibel olevad mõisted. Seega näib, et mõisted nagu neid vahendav keelgi on olemas enne meid ja me lihtsalt õpime neid kasutama.

Mida olemuslikku on eesti keel oma kasutajate jaoks sõnasse mõiste talletanud? Substantiiv mõiste on $e$-tuletis verbist mõistma, millel EKSS-i järgi on 4 põhilist

${ }^{4}$ Küll aga kultiveerivad mõned keeled arusaama mõistete katsutavusest, nt soome keeles on mõiste vasteks käsite, ka meie räägime mõistmisega paralleelselt käsitamisest. Inglise keelt kõnelevad rahvad suudavad aga mõisteid haarata (vt Jackendoff 1999). 
tähendust: (i) 'taipama, aru saama, selgusele jõudma', nt Ma mõistan, mida sa tunned; (ii) 'mõistatama', nt Mõista, mõista mis see on?; (iii) 'oskama', nt Kas sa saladust pidada mõistad?; (iv) 'hinnangut andma, otsust langetama, määrama', nt Kurjategija mõisteti süüdi. Seega võib mõiste olla seotud nii taipamise, äraarvamise, oskamise kui otsustamisega, mis kõik on seotud inimese vaimsete võimete rakendamisega.

Ehkki $e$-liitega tuletatakse regulaarselt teosubstantiive (nt teke $=$ tekkimine $)$ ja protsesside üksikjuhtumeid (nt hüpe vrd hüppamine), kuulub sõna mõiste "muude deverbaalide" rubriiki, mille tähendus võib olla nt tegevusvahend, saadus, tulemus (EKG I: 504). Seega võib mõiste olla mõistmise protsessis nii vahendiks, saaduseks kui tulemuseks. Tegu on kindlakskujunenud leksikoniüksusega, kus liite tähendust on sõnatähendusest raske eristada.

Verbi mõistma etümoloogia osutab, et tegu on vana soome-ugri sõnaga, millel on vasteid olemas paljudes sugulaskeeltes, nt on soome sõna muistaa 'mäletada' sama algupäraga (Mägiste 1982-1983). Algseks tüvekujuks on rekonstrueeritud ${ }^{*}$ muja-(Häkkinen 2004). Otsides sugulaskeelte toel selle verbi võimalikku algsemat ja konkreetsemat tähendust, jõuame lüüdi ja vepsa verbini mujada, tähendustega 'maitsta, katsuda, haista'. Seega on vaimsete tegevuste tähendused eesti ja soome verbidel mõistma ja muistaa tagasi viidavad tajuprotsesse nimetavale tähendusele, mis on hästi kooskõlas tendentsidega ka paljudes indo-euroopa keeltes (Sweetser 1990).

\section{Mõiste mitmest vaatenurgast}

Kõik teadusalad, mis mõistega tegelevad, on ühel meelel selles, et mõisted on hädavajalikud selliste komplekssete organismide nagu inimene edukaks toimetulekuks. On leitud, et meie kogemus oleks organiseerimatu kaos ja me ei suudaks sellest õppida, kui me ei lahterdaks seda stabiilsetesse kategooriatesse. Iga uus kogemus oleks kordumatu ja eelnevast ei oleks kasu selle interpreteerimisel. Jagatud kategooriaid peetakse ka suhtluse eelduseks (Cruse 2000: 127).

Oma spetsiifikast lähtuvalt defineeritakse mõistet eri teadusaladel siiski mõnevõrra erinevalt. Näiteks entsüklopeedia annab loogikast lähtuva definitsiooni: mõiste on "abstraktse mõtlemise vorm, mis peegeldab tegelikkuse esemeid ja nähtusi nende oluliste tunnuste, seoste ja suhete kaudu [---] Mõiste peegeldab tegelikkust adekvaatsemalt kui taju või kujutlus" (EE). Psühholoogias on mõistet defineeritud kui filtrit, mille läbi kogemust sõelutakse (Russell, Lemay 2000: 491), aga ka kui teadmiste hulka, mida vaikimisi kasutatakse kõrgemale tunnetusele aluseks olevates kognitiivsetes protsessides (Machery 2007: 20). Lingvistikas on defineeritud mõisteid kui salvestatud teadmiste kimpe, mis esindavad meie kogemuses esinevate sündmuste, entiteetide, situatsioonide jm liigendatust (Cruse 2000: 127).

Mida on mõistetel kui abstraktse mõtlemise vormidel, teadmiste kimpudel või tajufiltritel tegemist keeleteadusega? Lingvistiline perspektiiv mõistele saab alguse keelest, st vaevalt satuks lingvistide huviorbiiti mõiste ilma selle keelelise tähistuseta. Pigem on ikka vastupidi: lingvistika läheb liikvele keele uurimisest, ja kuivõrd keelemärk on tähistaja ja tähistatava ühtsus, siis tuleb kirjeldada ka tähistatavate tähendust. Siin tulebki mõnikord mängu mõiste. 
Denotatsioonide võimalikult täpses kirjeldamises on nähtud sõnasemantika ülesannet (Karlsson 2002: 238). Kui tegu ei ole just budistliku keelekäsitlusega, ${ }^{5}$ on keeleline tähendus määratletud positivistlikult: miski (tähistaja e keeleline sümbol) on vastavuses millegi muuga (tähistatav e referent). Näiteks sõnaga tool oleks justkui vastavuses tähistatav mööbliese. Asjad tähistatavaga pole siiski nii lihtsad: klassikalisena on käibel Charles Ogdeni ja Ivor Richardsi (1989 [1923]) semiootiline kolmnurk (vt joonis 1), mis reaalse maailma objekti kui võimaliku referendi kõrval seab sümboliga vastavusse ka mõtte või viite (ingl thought or reference). Viimane on sümboli suhe mõiste või ideega, st mingi kujutisega inimmeeles (Karlsson 2002). Pidev joon tähendab joonisel 1 otsest ja katkendjoon kaudset vastavust. Meie tooli näites seega tähistaks sõna tool otseselt mõtet toolist või viitamisseost tooli mõistega ja alles selle viitamisseose kaudu ka vastava esemega. Siin on mõiste käibel abistava terminina tähenduse olemuse avamisel.

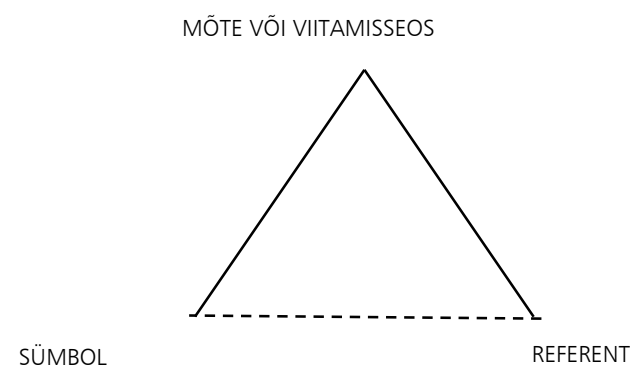

Joonis 1. C. Ogdeni ja I. Richardsi semiootiline kolmnurk (1989 [1923])

Samuti semantika klassikuks peetav John Lyons (1977: 96) asetab mõiste aga juba otse semiootilise kolmnurga tipuks (ingl signification), vahetades sellel kohal välja originaalis olnud mõtte või viitamisseose. Referendi asemel kasutab ta terminit significatum. Sõna tool on otseseoses mõistega tooL ja viimane on otseseoses tooli kui esemega. Üldistus, et keeleline sümbol kui tähistaja on vastavuses referendi e tähistatavaga mõiste kaudu, on kujunenud tunnustatud tõdemuseks. Sellist vaadet keele ja maailma seostele, mis määratleb väljendi või sõna tähenduse mõistena, on hakatud nimetama kontseptualismiks (Lyons 1977: 110).

Kuigi kirjanduses arutletakse jätkuvalt selle üle, kas üldse on olemas mingi abstraktne mõistete tasand, mis seisab eraldi sõnade tähendusest, või on sõnade tähendused mõistetega samastatavad (Aitchison 2003: 43), tundub, et üldiselt usutakse tänapäeval mingite keeleüksustele vastavate mentaalsete representatsioonide olemasolu inimese ajus. Käibel on terminid nagu mentaalne leksikon (Aitchison 2003) või mentaalkeel (mentalese, Pinker 2000). Järgnevalt tutvustamegi erinevaid lähenemisi mõistetele kui võimalikele tegelikkuse representatsioonidele.

\subsection{Klassikaline lähenemine}

Läbi ajaloo on arvatud, et kategooriad on kindlalt piiritletavad ja et leksikaalsed mõisted on määratletavad nende kasutamiseks vajalike ja piisavate tingimuste teadmise kaudu. Näiteks mõistet vANAPOISs me saaks kasutada, kui kõnealune isik

${ }^{5}$ Budistlikus keeleteoorias lähenetakse keele tähistusvõimele hoopis negatsiooni kaudu: näiteks sõnaga laud välistatakse mõeldavate asjade hulgast kõik, mis on olemuselt mittelaud (vt Thampi 2005). 
vastaks kõigile vajalikele tingimustele: VALLALINE, MEES ja TäISKASVANUd. Samas on need tingimused ka piisavad: igaüks, kes vastab neile tingimustele, kuulub automaatselt kategooriasse vaNAPOISS (vt lähemalt Laurence, Margolis 1999). Mõistetest mõeldakse kui abstraktsetest asjadest, millel on mahulise kasti omadused: vaimus mõeldud ese saab olla kas selle sees või väljas, mitte aga olla kuidagi serva peal ripakil. Kategooria sees on liikmed võrdse staatusega.

Selline selgeid piire ja kindlaid liikmesustingimusi rõhutav lähenemine mõistetele sobis hästi 1970-ndatel strukturalismist välja kasvanud objektivistlikule semantikakoolkonnale lingvistikas, mille raames peeti tähendusi entiteetideks, mida sai formaliseerida ja ka täpselt kirjeldada binaarses opositsioonis olevate tunnusepaaride abil (Karlsson 2002). Lisaks kontrastiprintsiibile oli oluline struktuuriprintsiip - tähendusi usuti koosnevat väiksematest üksustest, millest räägiti kui semantilistest komponentidest, tähenduse kirjeldust nimetati komponentanalüüsiks. Näiteks sõna mees tähendus oli määratletud kui +INIMENE, +TäISKASVANUD, +MEESSOOST, sõna naine tähendus erineb ühe komponendi, -MEESsoost, poolest; tüdruk aga on kirjeldatav kui +INIMENE, -TÄISKASVANUD, -MEESSOOST. Samu binaarseid tunnusekomplekte kasutavad mõisted moodustasid suuremaid üksusi e semantilisi välju, näiteks kuuluvad MEES, NAINE, POISS ja TÜDRUK välja 'INIMSUGU' (vt nt Leech 1990 [1974]: 89-122).

Klassikalisele mõistekäsitlusele toetub ka terminiarendus, mille raames näiteks Eesti terministandardis ${ }^{6}$ on mõiste määratletud kui teadmusüksus, mille moodustab tunnuste ühene kombinatsioon. Eri staatusega on olulised tunnused (nagu soo- ja liigitunnused), mis on mõiste mõistmiseks möödapääsmatud, ning eristavad tunnused, mis aitavad sugulasmõisteid üksteisest lahus pidada. Näiteks tooli mõiste võiks defineerida olulise tunnusega "mööbliese ühe inimese istumiseks" ja eristavaks tunnuseks võiks olla "leeni olemasolu", mis eristab seda sugulasmõistetest taburet ja järi. Nende tunnustega on määratletud selle mõiste sisu e intensioon. Selle mõiste ekstensiooni e mahu moodustavad kõik esemed, mis sellesse kategooriasse kuuluvad, kusjuures kogu maailma kirjususest hoolimata ei ole ükski tool põhimõtteliselt teistest "toolim".

Mõlemas tutvustatud lingvistilises rakenduses on tunda klassikalisele mõisteteooriale omast täpsust ja kategooriate jäikust. Mõiste rakendamise tingimuste asemel on lingvistilises tähendusekirjelduses vaid semantilised komponendid või tunnused. Mõistete psühholoogiline realistlikkus ei ole arutlusobjektiks.

\subsection{Prototüübiteooria}

Prototüübiteooria on osa üldisemast kognitiivsest pöördest inimtunnetuse mõistmisel, mis leidis aset eelmise sajandi viimasel veerandil, kui järjest enam hakati kilbile tõstma kategooriate kogemuslikkust ja psühholoogilist usutavust. 1970-ndatel korraldatud empiirilised katsed sõnatähenduste uurimiseks osutasid, et kategooriad, millega inimesed reaalselt otsustusi langetades opereerivad, on piiridelt hägused ja sisemiselt organiseeritud esindavate liikmete ehk prototüüpide ümber. Kategooria liikmelisus osutus astme küsimuseks, mida ei otsustata mingite kindlate tunnuste olemasolu või puudumise alusel, vaid sarnasuse põhjal tüüpilise esindajaga

6 Autorid tänavad Arvi Tavastit võimaluse eest tutvuda terministandardi EVS-ISO 1087-1:2002 projektiga. 
(Rosch 1978). Näiteks selle üle, mis mööbliesemega on tegemist meie istumise all, otsustame selle eseme sarnasuse põhjal tüüpilise tooliga. Ka prototüübiteoorias räägitakse siiski kategooriate tunnustest, kuid need ei ole vajalikud ja piisavad, vaid tõenäolised ja olulised (Rusell, Lemay 2000). Mida lähemal kategooria keskmele e prototüübile paikneb kõnealune mõeldav ese, seda enam ühiseid tunnuseid tal sellega arvatavasti on. Ükski tunnus eraldivõetuna siiski kuidagi kriitiline ei ole. Näiteks võib ka istumiskõlbmatu lagunenud tool olla siiski kategooria TooL liige, kuigi suhteliselt kauge tüüpilisest esindajast; samuti võib tooliks teatud tingimustel klassifitseerida istumiseks sobiva puunoti.

Kategooriatest hakati "kastisüsteemi" asemel mõtlema ruumiliselt, tsentri ja radiaalselt eemalduva perifeeria terminites. Võimalikuks osutusid kategooriatevahelised üleminekualad ning mõeldava eseme kuulumine korraga mitmesse kategooriasse. Mõistete prototüübiteooria on saanud väga laia kõlapinna lingvistikas (vt nt Erelt 1984), osalt kindlasti ka selle tõttu, et lingvistilised kategooriad ise alluvad prototüübi lähenemisele palju hõlpsamini kui "kastisüsteemile".

Lingvistilise semantika jaoks tõi see kaasa, et sõna tähendus ei olnud enam hõlpsasti defineeritav ega kirjeldatav semantiliste tunnuste abil. Mingi väljendi tähenduse kirjeldamine tähendas esitada nii selle tüüpilisemad kui ka ebatüüpilisemad kasutused, mis kõik koos moodustavad nn kimpesituse (ingl cluster) või radiaalse kategooria (vt joonis 2).

Prototüübiteooria sobib hästi seletama kategooriate hajusust ja on psühholoogiliselt usutav. Selles osas, kas kategooriat esindav prototüüp on olemuselt pigem abstraktne ja ideaalne skeem või konkreetne eksemplar, puudub teoreetikutel üksmeel (vt Russel, Lemay 2000: 494).

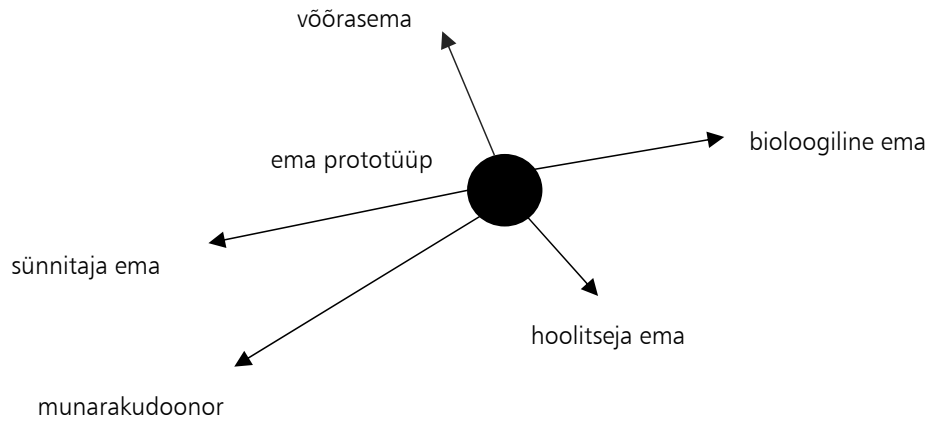

Joonis 2. Mõiste EMA radiaalne esitus (Lakoff 1987 järgi)

\subsection{Teooria teooria ${ }^{7}$ ning teadmiste sidusus}

Mõistete seondumine omavahel ja üldisemate tunnetusprotsessidega on pannud aluse nn teooriakesksele lähenemisele (Murphy, Medin 1999). Väidetakse, et ainuüksi sarnasusest kas mingile ideaalsele prototüübile või antud klassi parimale esindajale ei piisa mõistete sidususe seletamiseks. Mõisted on hoopis vaadeldavad lülidena mõistmisprotsessis, mis tähendab vaikimisi teooriate loomist selle kohta, kuidas on nähtused omavahel seotud. Suhe üldisemasse teooriasse otsustab, mil-

7 Kasutame siin terminit teooria teooria S. Laurence'i ja E. Margolise (1999: 43) eeskujul pisut laiemas tähenduses, kui seda on sarnase nime all tuntuks saanud tendents luua teooriaid teiste inimeste meeleseisundite kohta ingl nn theory theory of mind. 
lised omadused on olulised ja millised mitte. Näiteks KANA, PORGAND ja MANDEL pole kuidagi sarnased; omaduseks, mis seob neid kategooriaga тогт, on nende söödavus, mis omakorda on osa naiivsest toitumisteooriast (näide Russell, Lemay 2000: 495). On põhjust arvata, et näiteks emotsioonimõistete, aga ka isiksuseomaduste jagunemine positiivseteks ja negatiivseteks tagab vastava rahvaliku teooria sidususe üldise inimest käsitleva naiivteooriaga, mille aluseks on hea ja kurja polaarne vastandus (vt Vainik 2002, Orav 2006).

Lingvistilises semantikas on mõistete sidusust tähtsustav lähenemine toonud kaasa tähenduste kirjeldamise suhete kaudu üldisemate teadmisstruktuuridega, mida on nimetatud küll freimiks (Fillmore 1985), skriptiks (nt Wierzbicka 1999), kultuuriliseks mudeliks (D’Andrade 1987), kognitiiuseks stsenaariumiks (nt Lakoff, Kövecses 1987) või idealiseeritud kognitiivseks mudeliks (Lakoff 1987).

Freimi kui teadmiste struktuuri püütakse kirjeldada propositsioonidest koosneva kompaktse semantilise esituse abil, mida kutsutakse samuti freimiks. Selline esitus võib kirjeldada ka üksikmõistet, kuid enamasti kirjeldab mitut omavahel seotud mõistet. Näiteks JULGE ja ARG kui põhimõtteliselt sama situatsioonitüübiga seotud vastandlikke omadusi hõlmavad mõisted on Heili Oraval kirjeldatud ühe ja sama JuLGUSE freimi abil (vt joonis 3), mille elementidest vaid mõne vastandlikkus eristab kahte mõistet (Orav 2006: 82-83). Propositsioonides figureerivad üldistatud tähendusega freimielemendid, mis defineeritakse iga freimiesituse komplekti tarbeks selle eesmärke silmaspidavalt. Näiteks kirjeldab H. Orav eesti keele isiksuseomaduste sõnavara (ligi 1200 mõistet) ära, kasutades 15 defineeritud freimielementi.

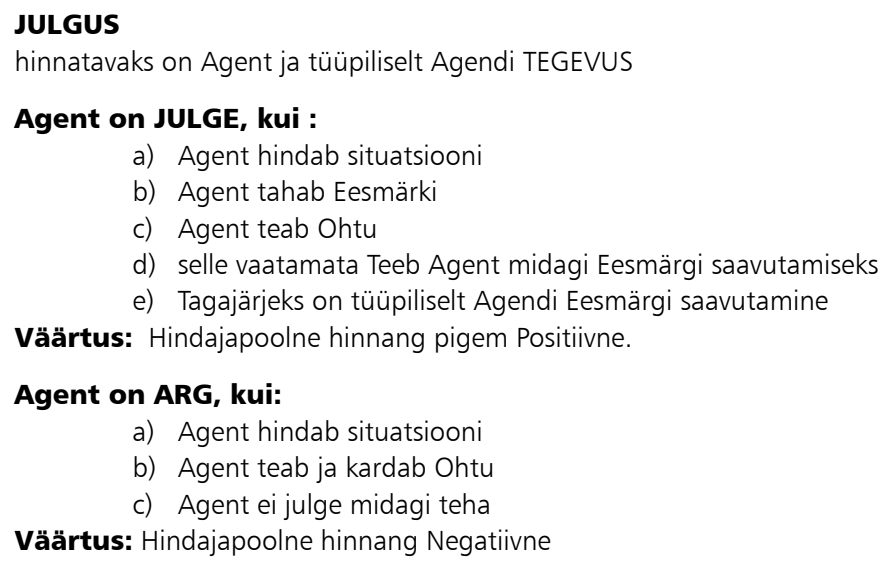

a) Agent hindab situatsiooni

b) Agent teab ja kardab Ohtu

c) Agent ei julge midagi teha

Väärtus: Hindajapoolne hinnang Negatiivne

Joonis 3. JULGUSE freim (Orav 2006)

Skriptid on teadmiste struktuuri esitused, mis kirjeldavad sündmuste ajalise ja/või põhjusliku järgnevusega seotud mõistestruktuure. Anna Wierzbicka on leidnud selle vormi olevat hästi sobiva emotsioonimõistete sisu avamiseks (1999). Ka skriptid koosnevad propositsioonijärjenditest, mis omakorda koosnevad piiratud arvust nn semantiliste metakeele primitiividest (vt nt Wierzbicka 1996). 


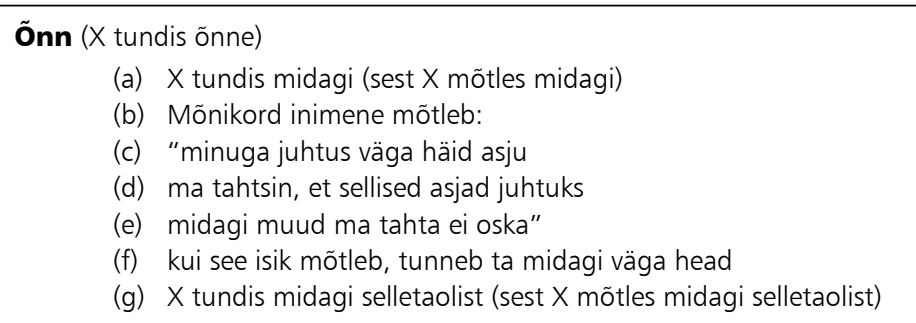

Joonis 4. Mõiste õnN skript (Wierzbicka 1999)

Stsenaarium e kognitiivne mudel on mõnevõrra vabam propositsioonijärjendeist koosnev mõiste kirjeldus, mis metakeelena kasutab tavalise keele piiramatuid vahendeid. On näiteks väidetud, et teada, mida tähendab inglisekeelne sõna anger 'viha', on sama, mis teada mõiste vıнA prototüüpset stsenaariumit e kognitiivset mudelit (Fehr, Russell 1984).

(1) Solvamine. Kahju põhjustaja solvab vastaspoole Mina. Solvav sündmus pahandab solvatu Mina. Kahju põhjustaja on süüdi. Rünnaku intensiivsus kaalub üles karistuse intensiivsuse (mida selles faasis ei ole) ja tekitab seega tasakaalutuse. Rünnak põhjustab viha tekkimise.

(2) Viha eksisteerimine. Sisaldab ka füsioloogilisi protsesse, mis on vastava emotsiooniga seotud; ekspressiivne komponent. Eksisteeriv viha avaldab Minale füsioloogilist mõju (kuumus, rõhumine, ärevus, erutus). Viha rakendab Mina suhtes jõudu, et üritada kätte maksta.

(3) Püüe viha kontrollida. Mina avaldab vastumõju, et viha kontrollida.

(4) Kontrolli kadumine. Viha intensiivsus ületab piirid. Viha valdab Mina, kes ilmutab vihast käitumist (otsustusvõime kadumine, agressiivne tegevus). Need nimetatud käitumisilmingud kahjustavad mina. Selles faasis on kahju põhjustanu ohus.

(5) Karistus, kättemaks. Mina sooritab pahategija suhtes kättemaksuakti. Kättemaksu intensiivsus tasakaalustab rünnaku intensiivsuse. Viha intensiivsus langeb nulli. Viha lakkab eksisteerimast.

Joonis 5. VIHA stsenaarium ameerika inglise keeles (Lakoff, Kövecses 1987)

Termin idealiseeritud kognitïune mudel sobib üldnimetuseks komplekssetele struktureeritud teadmistesüsteemidele. Need mudelid on idealiseeritud, kuna võtavad kokku seda teadmist, mis on kogemuseülene, samas aga ka selles mõttes, et võivad sisaldada kultuurilisi paleusi. Kui näiteks mõiste ABIELU idealiseeritud kognitiivne mudel oleks pelgalt statistiline, peaks see sisaldama konflikte ja vähemalt 50\%-lise tõenäosusega ka lahutust. Tegelikkuses näib aga ABIELu mõistesse kuuluvat soovmõtlemine "kui nad surnud ei ole, elavad nad õnnelikult tänase päevani".

Laiemaid teadmisstruktuure arvestavad lähenemised mõistetele üritavad seletada kategooriate radiaalset struktuuri ning mõistete prototüüpsusega seotud omadusi kui teadmiste üldise idealiseeritud mudelesituse kõrvalprodukte (Lakoff 1987: 68). Idealiseeritud kognitiivse mudeli rolli nähakse pidevalt toimivate mõistestusprotsesside ja mõtte vahetu meediumi - nn mentaalsete ruumide - struktureerijana (Lakoff 1987: 281). 


\subsection{Ruumiline lähenemine}

Mõte sõnade tähendust ruumiterminites kirjeldada ei olnud siiski uus ja läheb ajas isegi kaugemale tagasi kui prototüübiteooria. Charles Osgood, George Suci ja Percy Tannenbaum (1975 [1957]) käsitasid tähendust psühholoogilise fenomenina biheivioristlikus stiimuli ja reaktsiooni vaimus. Nende jaoks oli tähendus määratletud kui vahendusprotsess representatsioonisüsteemis, mis on ühteaegu märgi vastuvõtmise paratamatuks tagajärjeks ja märgile reageerimise vältimatuks eelduseks (Osgood jt 1975: 9). Tähendusprotsessi mõõtmiseks pakkusid nad välja semantilise diferentsiaali meetodi, mis tähendab sõnade/mõistete hindamist 7-astmelistel skaaladel, mille otstes on polaarsete tähendustega omadussõnad (nt külm-soe, kauge-lähedane). Selle meetodi abil erinevaid mõisteid hinnates jõudsid nad järeldusele, et kõik mõeldavad semantilised eristused taanduvad kolmele statistilisele faktorile, millele nad andsid nimeks hinnang (ingl evaluation), jõud (potency) ja aktiivsus (activity). ${ }^{8}$ Mingi mõiste tähendus indiviidi jaoks on operantselt määratletud vastavate faktorlaadungite jaotumusena kolmel dimensioonil; mõiste tähendus kultuuris kujutab endast vastavate keskmiste faktorlaadungite jaotumust. Nad nimetavad neid faktoreid semantilise ruumi kolmeks mõõtmeks. Lisaks ühe konkreetse mõiste paigutuse selgitamisele lubab see meetod kujutada ka tervet mõistete hulka ja nende vastastikuseid (ruumilisi) suhteid (Osgood jt 1975: 87-89). Vaata näitena joonist 6 , mis kujutab 24 eestikeelse emotsioonimõiste paigutust kolme statistilise faktoriga määratud semantilises ruumis. Mõisteid kirjeldavad andmed on kogutud 100 keelejuhilt semantilisele diferentsiaalile väga lähedase meetodiga (vt Vainik 2004).

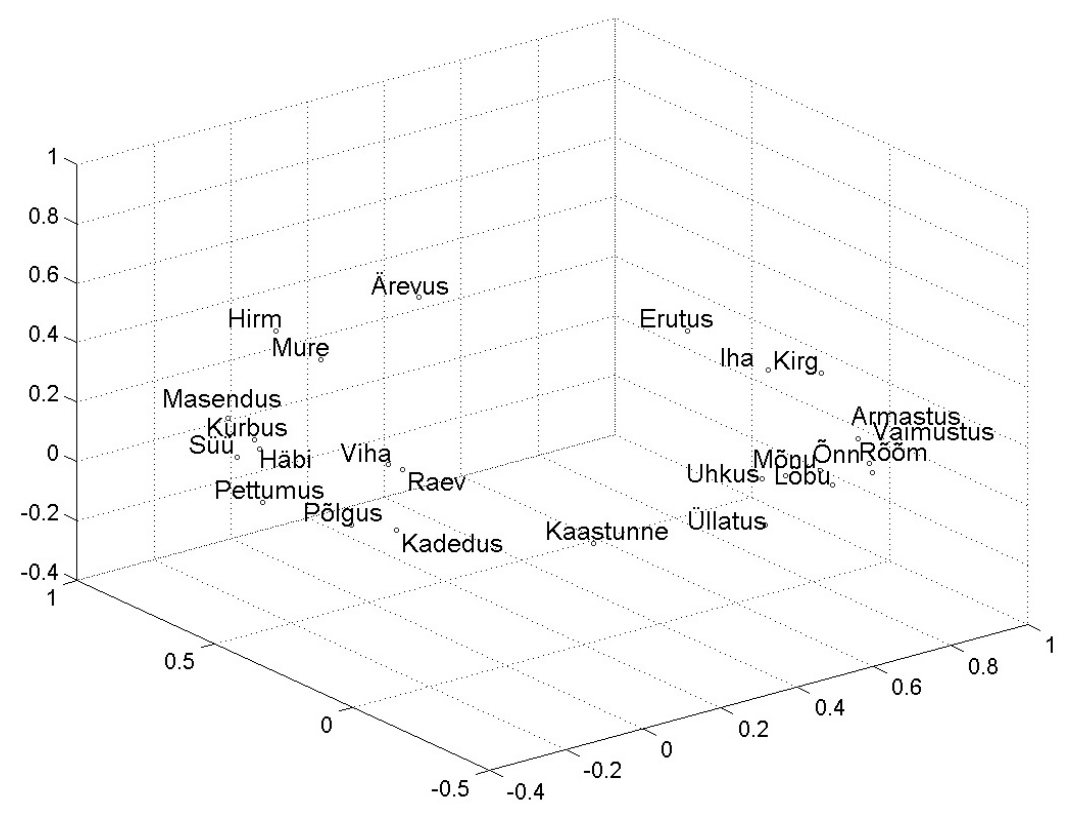

Joonis 6. 24 emotsioonimõistet kolme faktoriga määratud semantilises ruumis

8 Tähelepanuta on jäetud võimalus, et need kolm faktorit kirjeldavad pigem polaarsete adjektiivide mõõtmisvõimet kui nähtusi, mida nad "mõõdavad". 
Kognitiivse lingvistika raames kõneldakse ühelt poolt keele semantilisest ruumist kui piiramatu ulatusega mõistepotentsiaalide väljast (Langacker 1987, eesti keeles vt Vainik 1992) ja teiselt poolt rõhutatakse selle organiseeritust valdkondadena. Viimastest osa on nn abstraktsed valdkonnad, mis koosnevad ise teistest hõlmavamatest mõistetest. Näiteks mõistel sõRm on mõtet üksnes seoses hõlmavama mõistega KäsI. SõRM omakorda on valdkonnaks mõistetele KüÜs ja SÕRMENUKK. Nn põhivaldkonnad (ingl basic domains) nagu AEG, RUUM, AINE, KVANTITEET, MUUTUS on sellised, millele teised mõisted on taandatavad, kuid mis ise enam millekski ei taandu (Cruse 2000). Neist vähemalt AEG ja RUUM on iseloomustatavad otseselt ruumiliste dimensioonide abil. Enamus mõisteid on määratletud mitte ühe, vaid mitmest valdkonnast moodustuva valdkonnamaatriksi suhtes (vt nt Cruse 2000: 140, Langacker 1987, Evans, Green 2006: 230-247).

Kognitiivteadustes on mõistete ruumilise paigutuse ideed edasi arendanud Peter Gärdenfors $(1997,2000)$. Tema eesmärgiks on ühe geomeetrilise mudeli abil ära kirjeldada keele, meele ja maailma vahekorrad. Nn mõisteruumide teooria kohaselt on inimese käsutuses kolm põhimõtteliselt eristatavat representatsioonide tasandit. Välismaailmaga kõige rohkem on seotud nn eelmõisteline tase (ingl subconceptual level), kus mõisteid esindavad tajumodaalsustele vastavad kvaliteedidimensioonid. Kõige abstraktsem ja välise reaalsusega nõrgemalt seotud on sümboolsete representatsioonide tasand, kus mõisteid esindavad mingis keeles kasutatavad sümbolid, nt sõnad. Abstraktsuse astmelt vahepealne on nende kahe tasandi vahele jääv mõistelise representatsiooni tasand. Mõisted on kirjeldatavad alade või punktidena ruumis, mis on määratud eelmõistelise tasandi kvaliteedidimensioonidega (vt näiteks kolme dimensiooniga määratud värvimõistete paigutust jooniselt 7).

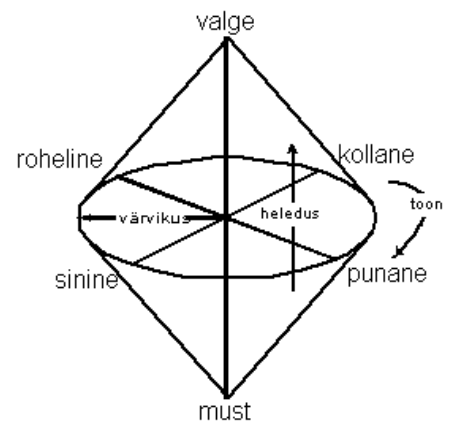

Joonis 7. Värvimõistete paiknemine mõisteruumis (Gärdenfors 2000)

Katseid mõistetega seotud tunnetusprotsesse ruumiterminites kirjeldada on tehtud teisigi. Näiteks mentaalsete ruumide teooria tegeleb põhiliselt tähenduse konstrueerimise uurimisega, sh eriti valdkondade vahelise ülekande (ingl mapping) probleemistikuga ja kognitiivsete segude (ingl blend) näol uute mentaalsete ruumide moodustamisega (Fauconnier 1994). 


\subsection{Võrgumudel}

Kuna kognitiivses lingvistikas kuulub mõiste kirjeldusse alati selle taustsüsteem, olgu siis abstraktse valdkonna või dimensioonide näol, siis on selge, et keeleline semantika ei saa enam olla autonoomne ning et mingi tähenduse täpne analüüs tähendab tunnetuse kogu arengu arvessevõttu (Langacker 2002). Viimane on aga seotud sellega, kuidas usutakse inimteadmised organiseeritud olevat. Ruumilise paigutuse ideega konkureerib teadmiste võrgumudel, millel rajaneb nn entsüklopeedilise semantika käsitus. Selle kohaselt on sõna sissepääsuks teadmiste võrgustikku, mis koosneb üksustest ja neid kaartena siduvatest suhetest. Näiteks sõna tähenduspoolusele kuuluvad antud indiviidil kõik selle sõlmega seostuvad teadmised, mälestused ja kogemused (Langacker 1987: 155).

Mõisteid kujutletakse seega sõlmedena kompleksses multidimensionaalses võrgustikus, kus nad on määratletud eelkõige seoste kaudu teiste mõistetega. Näiteks sõna hobune tähendus on mõiste новuNE ja see sisaldab mitmeid ning eri sorti seoseid teiste mõistetega. A. Cruselt (2000: 128) leiame järgneva mõiste HOBUNE esituse (vt joonis 8). Seosed võrgustikus kuuluvad teatud tüüpidesse (osa, liik, kasutusviis jne) ja on erineva tugevusega. Leksikaalne üksus aktiveerib mõiste ja sellega seotud mõisted teadmiste võrgustikus vastavalt seoste tugevusele ja esilduvusele. Võib oletada, et новuse puhul on kategoriseeriv suhe "on" mõistega LOoM esilduvam kui näiteks negatiivne kategorisatsiooniotsustus "ei ole" mõiste LEHM suhtes. Kategoriseerimise prototüübiloomus toimib ka siis, kui küsimus on semantiliste seoste tugevuses või esilduvuses.

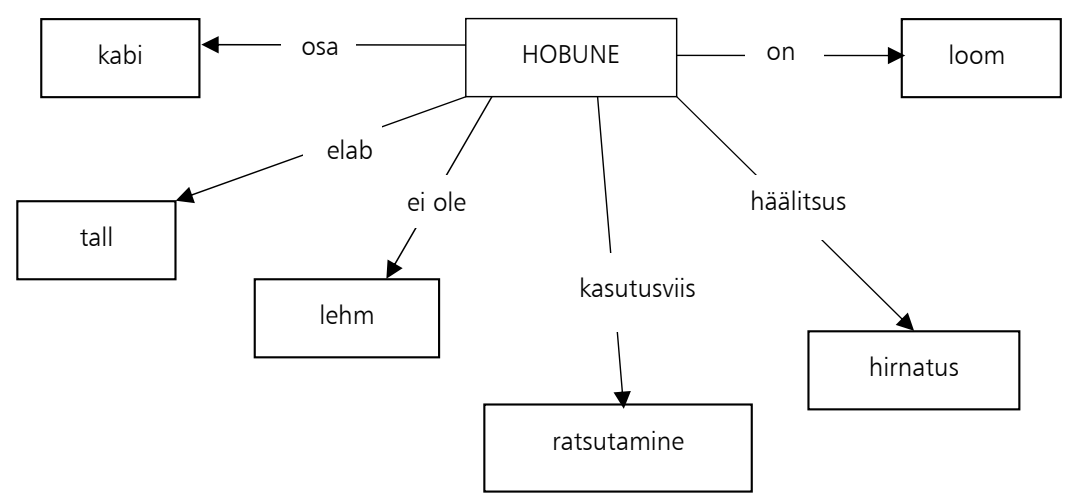

Joonis 8. Mõiste HOBUNE võrgustik (Cruse 2000)

On loomulik, et selliselt mõistetud mõiste ei ole täiesti muutumatu, vaid arenev vastavalt sellele, kuidas indiviidi teadmiste võrgustikku lisatakse uusi seoseid või sõlmi. Teadmiste võrgumudelile annab jumet asjaolu, et kui mõistetel on mingi neurofüsioloogiline korrelaat, siis seda tuleb näha pigem neuronite koaktivatsioonimustrina närvivõrgustikus, kui mingi selgelt lokaliseeritava või piiritletava üksusena inimese ajus. Teatavate närviühenduste hõlpsus võrreldes teistega taandub nende kasutussagedusele ning sellega seotud neuronite aktivatsioonilävede madalusele (Pinker 1997). 


\subsection{Dünaamiline lähenemine}

Mõistetest on võimalik mõelda ka mitte ainult kui suhteliselt stabiilsetest asjadest, vaid ka kui vaimsetest protsessidest, mis transformeerivad kogemuse toormaterjali käepärasteks üksusteks. Kuna välismaailma stiimulid on lõpmatult mitmekesised, siis tajus, mälus, mõtlemises, probleemide lahendamises ja teistes psühholoogilistes protsessides on ökonoomsem neid andmeid käsitleda teatavate tervikpakettidena, mis ühendavad omavahel piisavalt sarnanevaid stiimuleid. Mõistetest saab seega mõelda kui kognitiivse ökonoomia teenistuses olevatest protsessidest, kontseptualiseeringutest, mis on dünaamilised, hajusate piiridega ja individuaalsed (Russell, Lemay 2000: 492).

Sarnast mõtlemist võib tuvastada kognitiivses lingvistikas, kus deklareeriti tähenduse samastamist mõistestusega (ingl conceptualisation), ja hakati semantika esmaülesannet nägema mõtete ja mõistete struktuuri analüüsimises ning kirjeldamises (Langacker 1987, 2002, Evans, Green 2006). Mõistestamist käsitatakse seejuures üsna avaralt: see hõlmab nii uusi mõttemoodustisi (ingl conceptions) kui ka kinnistunud mõisteid; sensoorset, kinesteetilist ja emotiivset kogemust, vahetu sotsiaalse, füüsilise ja lingvistilise konteksti tuvastamist jne. Mõistestamine seisneb kognitiivses infotöötluses; kirjelduse ülesandena nähakse seda mentaalset kogemust moodustavate kognitiivsete sündmuste iseloomustamist (Langacker 2002). Teisal täpsustatakse, et kontseptualisatsiooni saab käsitleda kahel tasandil: (i) fenomenoloogilisel tasandil kui vaimset kogemust; (ii) kognitiivsete sündmuste tasandil kui näiteks neuroloogilist aktiivsust. Vaimse kogemuse protsess tähendabki mingit neuronaalse aktiivsuse ilmnemist ja vaimset kogemust on loomulik selle kaudu seletada, või vähemalt püüda tabada neile omast kognitiivsete sündmuste arhitektuuri (Langacker 2002: 149).

Lähenemises, mida on nimetatud ka uus-empiritsismiks (Machery 2007), on seda ülesannet võetud tõsiselt ja kujundatud käsitus mõistetest kui situatsiooniliste kontseptualiseeringute kogumitest (Feldmann Barrett 2006). Mõisted ei ole mitte üksnes dünaamilised, vaid ka multimodaalsed, st erinevate tajukanalite kaudu seotud situatsioonidega, millest nad võrsuvad.

Näiteks mõiste viнA ei ole mitte semantilises mälus paiknev klassikaliselt organiseeritud kogum infot, ega ka mitte prototüübi ümber organiseeritud tavaarusaam sellest emotsioonist. Mõiste viHA on pigem representatsioonide või kontseptuaalsete teadmiste pakkide kogum, mis kõik üksteisest erinevad. Iga kontseptualiseering on situatsioonisidus selles mõttes, et vastab antud isiku vajadustele antud olukorras. Kõik need juhtumid, kui kogetud tuumafekti on viha sõnaga tähistatud, annavad oma panuse viнa mõiste kujunemisse. Selliselt käsitatud mõiste on heterogeenne, varieerub ühel isikul vastavalt olukorra nõuetele, rääkimata varieerumisest isikute või kultuuride lõikes.

Mõisted kui situatsioonisidusad kontseptualiseeringud ei ole sõltumatud sensorimotoorsetest sündmustest ega talletatud mingit sorti propositsioonidena. Selle asemel käsitatakse neid tajusümbolitena (ingl perceptual symbols) ehk varem antud kategooria esinemisega kaasnenud sensorimotoorsete seisundite osaliste taaslavastustena, nn simulatsioonidena (Feldmann Barrett 2006, ja tema viited Barsalou jt 2003). On võimalik luua lõpmata palju erinevaid simulatsioone, mis sõltuvad hetke eesmärkidest ja situatsioonist, ning seetõttu on mõisteline esitus äärmiselt 
kontekstipõhine ja dünaamiline (Barsalou 2003). Igas olukorras aktiveeritakse teadmistest vaid olukorrale vastav osa. Näiteks otsustab mingi konkreetse situatsiooni aspekt, kas relevantne on see viha mõisteesindus, mis sisaldab karjumist, ründamist, hammaste krigistamist või nutmist (Feldmann Barrett 2006: 33).

Sarnased ideed on jõudnud ka lingvistikasse. Näiteks on uuritud tegevusverbide, nagu inglise grasp 'haarama', neuroloogilist esindatust ajus ja leitud, et samad taju ja liikumisega seotud närvikeskused/neuronid aktiveeruvad nii reaalse liigutuse, selle visuaalse taju korral kui ka vastava mõiste meenutamisel. Osutus, et millegi sooritamine ning selle pelk kujutlemine kasutavad sama neuronaalset substraati. Need tulemused lubavad autoritel väita, et kontseptuaalne teadmine on kehapõhine (ingl embodied), rajanedes meie sensorimotoorsel süsteemil (Gallese, Lakoff 2005). Kuivõrd viimane on multimodaalne (hõlmates nägemise, kuulmise, puudutuse, liikumise jne), on seda ka keel, mis tänu inimese ajus leiduvatele peegelneuronitele on võimeline juba olemasoleva tajumodaalsuste süsteemi uutmoodi kasutusele võtma.

Vittorio Gallese ja George Lakoff kõnelevad kehamõistetest (ingl embodied concept) kui skeemidest, mis sugenevad meile sotsiaalsest ja füüsilisest interaktsioonist maailmaga vastavalt meie keha ja aju olemuslikele parameetritele (Gallese, Lakoff 2005: 12). Ka nn põhitasandi kategooriate (Rosch 1978) esilduvuse ühe põhjusena toovad nad välja, et meil on sensorimotoorsed programmid, suhestumaks näiteks pigem tooli ja LAUAGA kui мööвLIGA üldiselt. Piltlikult öeldes: seda mis on tool, teab kõige paremini tagumik.

Kokkuvõttes väidab lähenemine, mida siin dünaamiliseks nimetasime, et mõisted/tähendused ei ole ei stabiilsed ega invariantsed, et nad on loomult multimodaalsed ja sugenevad inimese interaktsioonist keskkonnaga. Kognitiivne ökonoomia ei avaldu ainult kogemuse paljususe kokkuvõtmises väiksemasse arvu mõistetesse, vaid ka tajuesinduste kaasatuses mõistelisse representatsiooni.

\subsection{Evolutsiooniline lähenemine}

Kui juba on jõutud mõistete/tähenduste protsessiloomuse tõdemiseni, siis on loomulik ka küsida, milleks meile sellised protsessid? Mõistete eksistentsiks vajaliku, kuid samas ka väga energianõudliku aju väljakujunemine evolutsiooni käigus on pidanud andma selle omanikele eeliseid kas siis loodusliku või sugulise valiku survet silmas pidades.

Mõistete moodustamise (ingl concept formation) ja sümbolite põhinemise (ingl symbol grounding) uurimine on kaks suunda kognitiivteadustes, mis neile küsimustele püüavad vastata. Silmas peetakse ka seda, et kirjeldatavaid protsesse peaks olema võimalik arvutil modelleerida. Näiteks nähakse mõistete moodustumise analoogiat andmete klassifitseerimises ning sarnase käitumisega alamklasside leidmisele suunatud andmeanalüüsi ja -kaevandamise meetodites ${ }^{9}$ (Witten, Frank 2005).

Mõiste moodustamiseks nimetatakse protsessi, mille käigus isik õpib korraldama teatud kogemust üldisteks reegliteks või klassideks (Britannica). Tegevuses tõstab isik üles konkreetse eseme, mõtetes kasutab ta aga klasse, teades eseme omadusi üldiselt. Selline üldistatud teadmine võimaldab toime tulla uutes situat-

9 Näiteks leiab P. Gärdenfors (2000), et iseorganiseeruvate kaartide meetod (Kohonen 2000) võimaldab leida mõisteruumi varjatud dimensioonid ning tuua välja andmetes peituva mõistete struktuuri. Formaalne mõistete analüüs (Ganter, Wille 1998) püüab leida mõistelist kuuluvust omaduste ja objektide vaheliste seoste kaudu. 
sioonides. Sümbolite põhinemist seletatakse kolmetasandilise struktuuri kaudu, milles madalaim tase on mõiste moodustamiseks vajaliku sensoorse informatsiooni projitseerimine ikooniliseks esituseks, järgnev tase on teatud omadusi üldistav kategoriaalne esitus esinevatest mustritest ning kõrgemaks tasemeks on mustri sidumine sümbolitega (Harnad 1990).

Vastust küsimusele, miks sellised protsessid aset leiavad, nähakse alalhoiuinstinktis. ${ }^{10}$ Tähenduse omistamist nähakse kogu elusloodusele omase fenomenina (Hoffmeyer 1996). Füüsilise keskkonna projektsioon mõisteliseks esituseks ei toimu üks-üheselt, vaid on piiratud organismi vajadustega edukaks toimetulekuks antud keskkonnas. Klassifitseerimise täpsus peab olema vastavuses olulisusega organismi eksistentsi seisukohast ning peab võimaldama maksimaalset teavet keskkonna kohta minimaalse kognitiivse kuluga (Rosch 1978).

Ainult klassifitseerimine ei kirjelda aga asjade kogu tähendust ning seepärast on mõned uurijad leidnud, et lisaks sündmust või objekti füüsiliselt kirjeldavatele dimensioonidele on mõistete moodustamisel oluline ka väärtuse (inglvalue) dimensioon (Zlatev 2001). Asjaomases kirjanduses nimetatakse seda ka tähenduseks (ingl meaning) ning väidetakse, et teadmine objekti või sündmuse tähendusest (= väärtusest) sugeneb läbi tagasisideahelate (Cisek 1999). Organismi heaolu soodustavad objektid või sündmused (nagu toit) hinnatakse headeks ja seda kahjustavad nähtused (nagu oht) halbadeks. Selline eristamine annab tähenduse nii tajule - kas tajutav objekt või sündmus võimaldab saavutada soovitud olekut või annab märku võimalikust ebasoovitavast olekust - kui ka tajude põhjal moodustatud mõistetele. ${ }^{11}$ Viimaseid salvestatakse mälus kui hulka neuronite klikke, mis kodeerivad erinevaid tunnuseid/omadusi üldistest spetsiifilisteni ning on leitud, et sealhulgas talletatakse ka sündmusega kaasnenud emotsionaalset kogemust (Lin, Osan, Tsien 2006). Emotsionaalne info annabki mõistele väärtuse.

Edukus olelusvõitluses ei sõltu ainult katse ja eksituse teel saadavast tagasisidest, oluline on hinnata ka seda, mida objektid või sündmused meil lubavad saavutada. Lapsed õppivad juurde uusi mõisteid, sõnu, objekte ja sündmusi mitte niivõrd nende omaduste kaudu, vaid vastavalt sellele, mida need võimaldavad neil peale hakata (Gibson 1979).Väidetakse ka, et kategooriad, mida me maailma tunnetamiseks kasutame, on eesmärgistatud, ning et kategooria kõige tüüpilisemad näited on need, mis suurendavad eesmärgi saavutamist, mitte ilmtingimata need, mis on sagedased (Feldmann Barrett 2006).

Ei saaks öelda, et evolutsioonilise kasulikkuse argumendid oleks kuigi laialdaselt lingvistilisse semantikasse jõudnud. Katseid keelenähtusi olelusvõitlusega seletada võib siiski leida nt E. Vainiku (2002) ja H. Orava (2006) töödest, kes on uurinud emotsioonide ja isiksuseomaduste sõnavara semantikat ning leidnud sealt läbiva jaotuse heaks ja halvaks. Evolutsiooniline lähenemine sobib hästi mõningaid nähtusi seletama, kuid empiirilisi tõendeid selle toimimisest on raske saada, kasvõi juba sellepärast, et evolutsioon on oma olemuselt väga pikaajaline protsess. Lahenduseks võiks olla mõistemoodustuse modelleerimine arvutil. Näiteks on spetsiaalse programmi loomisega simuleeritud algselt teadvusetute agentide evolutsiooni "toitvate" ja "toitmatute" objektide keskkonnas, kus nood mitme põlvkonna möödudes omandasid teadvuse alged, st võime klassifitseerida keskkonnas olevaid objekte ja nähtusi ning luua nendest elementaarse mõistelise esituse (vt Kirt 2007).

${ }^{10}$ Nn NASA määratluse järgi on elu ennast alalhoidev keemiline süsteem, mis järgib darvinistliku evolutsiooni põhimõtteid (Shapiro 2007). Elu aluseks peetakse autokatalüütilisi tsükleid (Kauffman 1993). Elusate süsteemide peamine omadus on tagada eksistentsiks vajalikud tingimused ning seetõttu hoida teatud parameetreid soovitud vahemikus.

11 On tähelepanuväärne, et ka C. Osgood, G. Suci ja P. Tannenbaum (1975) jõudsid semantilise diferentsiaaliga mõisteid mõõtes tulemusele, et hinnangu dimensioon seletas kaks korda nii palju vastuste variatiivsust kui jõud või aktiivsus, viimaste laadung ületas kaks korda mistahes järgnevat faktorit. 


\section{Kokkuvõte ja arutelu}

Mõiste mõistmise ja seletusviiside mitmekülgsus, mida eelnevas tutvustasime, annab aimu nendest jõupingutustest, mida inimkond on sellest nähtusest aru saamiseks teinud. Meie eesmärgiks ei olnud välja selgitada ühte ja “õiget” mõistete mõistmise viisi. Tahtlikult hoidusime erinevatele lähenemistele hinnanguid andmast, keskendudes selle asemel mõisteteooriate vastasmõjudele lingvistilise semantikaga, mille jaoks on pea igas lähenemises olnud midagi kasulikku ja edasiviivat. Osutub, et tähenduste kirjeldamine, seletamine ja modelleerimine on erinevad eesmärgid, millest lähtuvalt on ka lingvistikas katsetatud erinevaid semantilisi esitusi.

Keelelise tähenduse uurija võikski teha enda jaoks teoreetilise valiku lähtuvalt eesmärgist. Kui eesmärgiks on tähenduste täpne kirjeldamine ja fikseerimine (nagu sõnaraamatutöös, terminiarenduses või arvutilingvistilistes rakendustes), tuleks usutavasti valida klassikalisel mõisteteoorial põhinev komponentanalüüs või ka teooria teoorial põhinev kirjeldusatribuutika piiratud arvu selgelt määratletud primitiivide abil. Tesauruse tüüpi rakendusele sobib tähenduste võrgumudel oma defineeritud seosetüüpidega. Kui eesmärgiks on tähendusloomega seotu psühholoogiline seletamine, sobib prototüübiteooria. Kui semantikast liigutakse edasi mentaalsete representatsioonide arhitektuuri kirjeldamisele, võiks kaaluda ruumilist või dünaamilist lähenemist. Evolutsioonilise vaatenurga rakendatavus lingvistilises semantikas alles selgub. Huvitatule annab see igatahes võimaluse keelest leitavaid fenomene siduda kõikjal eluslooduses iseenesest aset leidvate protsessidega.

Mõiste uurimist raskendab asjaolu, et ta on ise mõiste ja et enamus mõisteid kirjeldavatest teooriatest on paratamatult sunnitud nende olemust määratlema teistele mõistetele toetudes. Katsed kirjeldada mõisteid/tähendusi mingit sorti semantiliste komponentide, primitiivide, freimielementide, kvaliteedidimensioonide, tajumodaalsuste, sensorimotoorsete esinduste või muu ontoloogiliselt "primitiivsema" kirjeldusatribuutika varal kujutavad endast kõik katseid sellest nõiaringist pääseda. Järjest nutikamate semantiliste kirjelduste väljamõtlemine on seotud ühelt poolt sooviga muuta silmale nähtamatud representatsioonid nähtavaks ja manipuleeritavaks ning teiselt poolt sooviga mõisteid ja mõistmisprotsessi tervikuna mõista ning modelleerida.

Mida me mõistest praegu rohkem mõistame kui artikli alguses? Kindlasti seda, et tegu on kompleksse nähtusega inimtunnetuses, mida saab käsitleda eri vaatenurkadest, tuues esile selle erinevaid olemuslikke tunnusjooni ja käitumist. Joonis 9 esitab kokkuvõtlikult lülisid, mis erinevates mõisteteooriates oluliseks on osutunud.

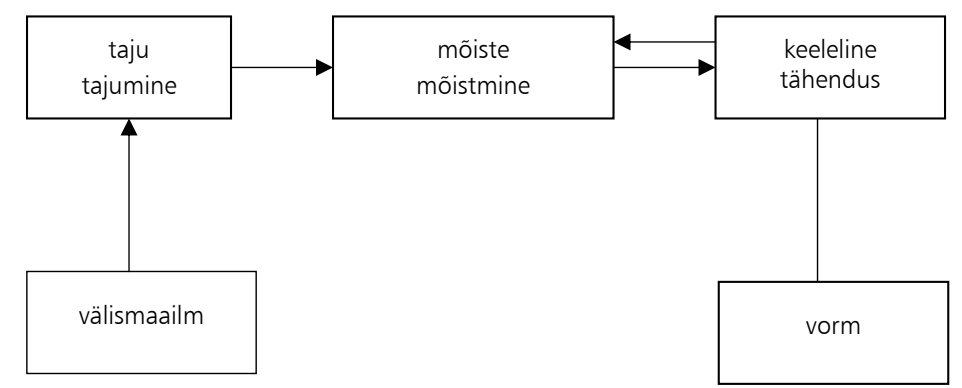

Joonis 9. Representatsioonitasandite koondesitus (Evans, Green 2006: 7) 
Paremal näeme keelemärki kui tähenduse ja vormi vastavust, mis mõjutab mõistmist ja mõisteid. Vasakul näeme aga välismaailma, mis läbi tajuprotsesside meieni jõuab ning mõistete kujunemisele aluse paneb. Joonisel on välja toodud keelelise tähenduse ja mõistete omavaheline vastasmõju, viimaseid on käsitatud kui tajudest tulenevaid representatsioone, mis on seotud keelelisele sümbolile omase tähendusega (Evans, Green 2006). Jooniselt puudub aga mõistete (tagasi)mõju tajule ja muudele tunnetusprotsessidele, mille olemasolu mõningad uuringud on samuti näidanud (nt Halberstadt, Niedenthal 2001).

Mõisted on kahepalgelised, kuuludes ühest küljest tähendusena sõnade (st keele) juurde ning olles seega kollektiivsed ja jagatavad; teisest küljest võtavad mõisted kokku kogemust ja teadmisi, mida igaüks on maailma nähtuste kohta individuaalselt oma teadmistesse talletanud. Neid kahte põhimõttelist mõistete tüüpi on nimetatud erinevalt, nt objektiivseks vs. vaimumõisteks (ingl mental concept) (Lyons 1977) või eksternaliseeritud vs. internaliseeritud mõisteteks (Jackendoff 1999). Kahe põhimõtteliselt erineva lähenemise võimalusest on tingitud vähemalt osa teoreetilisest möödarääkimisest eri alade kirjandustes. Keeleteaduses on tegeldud rohkem mõistete kollektiivsusest ja suhtluslikkusest tuleneva loomusega; psühholoogias ja kognitiivteadustes on keskendutud enam mõistmisprotsessidele indiviidis.

Ajalises perspektiivis on mõisteuurijate huvi liikunud üha enam mõistete määratlemise ja defineerimise probleemistikult nende psühholoogilise realismi ja neuropsühholoogiliste korrelaatide leidmisele. Suhteliselt pikalt on oldud üksmeelel, et mõisted on loomult amodaalsed, st sõltumatud mingi konkreetse tajukanali spetsiifikast (Machery 2006). Neid on peetud stabiilseks ideograafiliselt (st samal isikul on nad alati samased) ja nomoteetiliselt (st kõigil isikutele samas kultuuris on asjast enam-vähem samane ettekujutus) (Feldmann Barrett 2006: 32). Nagu näitasime dünaamiliste ja evolutsiooniliste mõisteteooriate tutvustuses, on tänapäevaks nende seisukohtade üksmeel kõikuma löönud.

Huvitav on veel tähele panna tutvustatud teoreetiliste mõistekäsitluste kattuvusi artikli algul esitatud naiivsete arusaamadega. Esiteks on see olnud vajadus elunähtusi kokku võtta ja nendega manipuleerida (nt käsitada või haarata), mis on sundinud mõistetest mõtlema "klassikalisel" viisil kui mahulistest kategooriatest ja objektidest. Teisalt on põnev, et eestikeelse sõna mõiste etümoloogia viib tagasi maitsmis-, katsumis- ja haistmisaistingutele, olles sellega kooskõlas vana hea empiritsismi, aga ka vägagi tänapäevase mõistete multimodaalsuse teooriaga. Dünaamilise vaatenurgaga haakub ka eestikeelse sõna mõiste vormiline kuulumine $e$-deverbaalide klassi, mis laseb sellega tähistatavat tõlgendada mõistmisprotsessi lülina. Verbi mõistma hinnangut sisaldav tähendus (nt õigeks vs. hukka) osutab aga paralleelsusele evolutsioonilise lähenemisega ja selles välja toodud positiivse ja negatiivse tagasiside funktsiooniga. Mõistmise ja mõistete tähtsus pole seega mitte ainult klassifitseerivas teadmises nähtuste omadustest, vaid ka automaatses hinnangus, mida mõistja selles olukorras ette võiks võtta. Ehkki meie oma artiklis hinnangutest tahtlikult hoidusime, andsime meiegi vihjeid, mida ühe või teise mõiste mõistmise viisiga saab lingvistikas peale hakata.

Kui püüda lõpetuseks vastata pealkirjas esitatud küsimusele, siis tuleb välja, et mõisteid saabki mõista mitmel eri viisil. Olenemata vaatenurkade paljususest ollakse üksmeelel selles, et mõisted ja mõistmine on kesksel kohal meie arusaamises keele, maailma ja inimmeele vastastikustest seostest. 


\section{Kirjandus}

Aitchison, Jean 2003. Words in the Mind: An Introduction to the Mental Lexicon. 3rd ed. Blackwell Publishing.

Barsalou, Lawrence W. 2003. Situated simulation in the human conceptual system. - Language and Cognitive Process 18 (5-6), 513-562.

Barsalou, Lawrence W.; Simmons, W. Kyle; Barbey, Aron K.; Wilson, Christine D. 2003. Grounding conceptual knowledge in modality-specific systems. - Trends in Cognitive Sciences 7, 84-91.

Britannica. Concept formation. Encyclopædia Britannica. http://www.britannica.com/eb/ article-70206 (18.06.2007).

Cisek, Paul 1999. Beyond the computer metaphor: Behaviour as interaction. - Journal of Consciousness Studies 6 (11-12), 125-142.

Cruse, Alan D. 2000. Meaning in Language. An Introduction to Semantics and Pragmatics. Oxford Textbooks in Linguistics. Oxford: Oxford University Press.

D'Andrade, R. G. 1987. A folk model of the mind. - Dorothy Holland, Naomi Quinn (eds). Cultural Models in Language and Thought. Cambridge: Cambridge University Press, 112-148.

$\mathrm{EE}=$ Eesti Entsüklopeedia. 1992. Tallinn: Valgus.

EKG I = Erelt, Mati; Kasik, Reet; Metslang, Helle; Rajandi, Henno; Ross, Kristiina; Saari, Henn; Tael, Kaja; Vare, Silvi 1995. Eesti keele grammatika. I. Morfoloogia. Tallinn: Eesti Teaduste Akadeemia Eesti Keele Instituut.

EKSS $=$ Eesti kirjakeele seletussõnaraamat. I-VII. Tallinn: Eesti Keele Instituut, 19882007.

Erelt, Mati 1984. Prototüübid ja keeleteadus. - Keel ja Kirjandus 2, 86-97.

Evans, Vyvyan; Green, Melanie 2006. Cognitive Linguistics. An Introduction. London: Lawrence Erlbaum Associates Publishers.

EVS-ISO 1087-1 = Terminoloogiatöö. Sõnastik. Osa 1: Teooria ja rakendus. Tallinn: Eesti Standardikeskus, 2002.

Fauconnier, Gilles 1994. Mental Spaces. Aspects of Meaning Construction in Natural Language. New York: Cambridge University Press.

Fehr, Beverley; Russell, James. A. 1984. Concept of emotion viewed from a prototype perspective. - Journal of Experimental Psychology 113 (3), 464-486.

Feldmann Barrett, Lisa 2006. Solving the emotion paradox: Categorization and the experience of emotion. - Personality and Social Psychology Review 10 (1), 20-46.

Fellbaum, Christiane (ed.) 1999. Wordnet. An Electronic Lexical Database. Language, Speech, and Communication. London: The MIT Press.

Fillmore, Charles 1985. Frames and the semantics of understanding. - Quaderni di Semantica $6.2,222-254$.

Gallese, Vittorio; Lakoff, George 2005. The brain's concepts: The role of the sensory-motor system in conceptual knowledge. - Cognitive Neuropsyhology 22, 455-479.

Ganter, Bernhard; Wille, Rudolf 1998. Formal Concept Analysis: Mathematical Foundations. Berlin: Springer-Verlag.

Gibson, James J. 1979. The Ecological Approach to Visual Perception. Hillsdale, NJ: Lawrence Erlbaum.

Gärdenfors, Peter 1997. Meanings as conceptual structures. - M. Carrier, P. Machamer (eds). Mindscapes: Philosophy, Science, and the Mind. The Pittsburgh-Konstanz Series in the Philosophy and History of Science. Pittsburgh: Pittsburgh University Press, 61-86.

Gärdenfors, Peter 2000. Conceptual Spaces. The Geometry of Thought. London: The MIT Press.

Halberstadt, Jamin P.; Niedenthal, Paula M. 2001. Effects of emotion concepts on perceptual memory for emotional expressions. - Journal of Personality and Social Psychology $81(4), 587-598$. 
Harnad, Stevan 1990. The symbol grounding problem. - Physica D 42, 335-346.

Hoffmeyer, Jesper 1996. Signs of Meaning in the Universe. Translated by B. J. Haveland. Advances in Semiotics. Bloomington: Indiana University Press.

Häkkinen, Kaisa 2004. Nykysuomen etymologinen sanakirja. Juva: WSOY.

Jackendoff, Ray 1999. What is a concept that a person can grasp it? - E. Margolis, S. Laurence (eds). Concepts: Core Readings. Cambridge, MA: MIT Press, 306-333.

Karlsson, Fred 2002. Üldkeeleteadus. Tõlkinud ja kohandanud R. Pajusalu, J. Valge, I. Tragel. Tallinn: Eesti Keele Sihtasutus.

Kauffman, Stuart 1993. The Origins of Order: Self-Organization and Selection in Evolution. Oxford: Oxford University Press.

Kirt, Toomas 2007. An agent based simulation for testing the emergence of meaning. - System and Information Science Notes 2 (1), 70-73.

Kohonen, Teuvo 2000. Self-Organizing Maps. 3rd ed. Springer Series in Information Sciences. Berlin: Springer-Verlag.

Lakoff, George 1987. Women, Fire and Dangerous Things: What Categories Reveal about the Mind. Chicago: The University of Chicago Press.

Lakoff, George; Kövecses, Zoltan 1987. The cognitive model of anger inherent in American English. - D. Holland, N. Quinn (eds). Cultural Models in Language and Thought. Cambridge: Cambridge University Press, 195-221.

Langacker, Ronald W. 1987. Foundations of Cognitive Grammar I. Theoretical Prerequisites. Stanford: Stanford University Press.

Langacker, Ronald W. 2002. Concept, Image, and Symbol. The Cognitive Basis of Grammar. Cognitive Linguistic Research. Berlin: Mouton de Gruyter.

Laurence, Stephen; Margolis, Eric. 1999. Concepts and Cognitive Science. - E. Margolis, S. Laurence (eds). Concepts: Core Readings. Cambridge, MA: MIT Press, 3-81.

Leech, Geoffrey 1990 [1974]. Semantics. Harmondsworth: Penguin Books.

Lin, Longnian; Osan, Remus; Tsien, Joe Z. 2006. Organizing principles of real-time memory encoding: Neural clique assemblies and universal neural codes. - Trends in Neurosciences 29 (1), 48-57.

Lyons, John. 1977. Semantics. Cambridge: Cambridge University Press.

Macherey, Edouard 2007. Concept empiricism: A methodological critique. - Cognition 104, $19-46$.

Murphy, Gregory; Medin, Douglas 1999. The role of theories in conceptual coherence. - E. Margolis, S. Laurence (eds). Concepts: Core Readings. Cambridge, MA: MIT Press, $425-458$.

Mägiste, Julius 1982-1983. Estnisches etymologisches Wörterbuch. 1-12. Helsinki: FinnischUgrische Gesellschaft.

Ogden, Charles K., Richards, Ivor A. 1989 [1923]. The Meaning of Meaning: A Study of the Influence of Language Upon Thought and of the Science of Symbolism. London: A Harvest/HBJ Book; New York: Harcourt Brace.

Orav, Heili 2006. Isiksuseomaduste sõnavara semantika eesti keeles. Dissertationes Linguisticae Universitatis Tartuensis 6. Tartu: Tartu Ülikooli Kirjastus.

Osgood, Charles E.; Suci, George J.; Tannenbaum, Percy H. 1975 [1957]. The Measurement of Meaning. Urbana-Chicago: University of Illinois Press.

Pinker, Steven 1997. How the Mind Works. London: Penguin Books.

Pinker, Steven 200o. The Language Instinct. London: Penguin Books.

Rosch, Eleanor 1978. Principles of categorization. - E. Rosch, B. B. Lloyds (eds). Cognition and Categorization. Hillsdale, NJ: Erlbaum, 27-48.

Russell, James A.; Lemay, Ghyslaine 2000. Emotion concepts. - M. Lewis, J. Haviland-Jones (eds). Handbook of Emotions. 2nd ed. New York: The Guilford Press, 491-503.

Saareste, Andrus 1958. Eesti keele mõisteline sõnaraamat I. Stockholm: Vaba Eesti.

Shapiro, Robert 2007. A simpler origin for life. - Scientific American 296 (6), 25-31. 
Sweetser, Eve 1990. From Etymolgy to Pragmatics: Metaphorical and Cultural Aspects of Semantic Structure. Cambridge Studies in Linguistics 54. Cambridge: Cambridge University Press.

Zlatev, Jordan 2001. A hierarchy of meaning systems based on value. - C. Balkenius, J. Zlatev, H. Kozima, K. Dautenhahn, C. Breazeal (eds). Proceedings of the First International Workshop on Epigenetic Robotics, Modeling Cognitive Development in Robotic Systems. Lund: Lund University Cognitive Studies, 153-162.

Tavast, Arvi 2004. Mõiste mõiste: tähendusteooriate mõju oskuskeelepraktikale. - Rahvusvaheline terminoloogiakonverents "Eesti oskuskeel 2003" 10. ja 11. oktoobril 2003. Ettekanded. Eesti Terminoloogia Ühing, Eesti Keele Instituut, Emakeele Selts. Tallinn: Eesti Keele Sihtasutus, 7-18.

Thampi, Mohan, G. B. 2005. Budistlik keeleteooria. - Akadeemia 6, 1161-1174.

Vainik, Ene 1992. Genereerib inimene, mitte grammatika. - Keel ja Kirjandus 3, 156-160, 4, 216-223.

Vainik, Ene 2002. Kas eestlased on "kuumaverelised"? Eestlaste rahvalikust emotsioonikategooriast. - M. Erelt, E. Ross, A. Õim (toim.). Emakeele Seltsi aastaraamat 47 (2001). Tallinn: Emakeele Selts, 63-86.

Vainik, Ene 2004. Lexical Knowledge of Emotions: The Structure, Variability and Semantics of the Estonian Emotion Vocabulary. Dissertationes Linguisticae Universitatis Tartuensis 5. Tartu: Tartu University Press.

Wierzbicka, Anna 1996. Semantics. Primes and Universals. Oxford: Oxford University Press.

Wierzbicka, Anna 1999. Emotions Across Languages and Cultures: Diversity and Universals. Studies in Emotion and Social Interaction. Cambridge: Cambridge University Press.

Witten, Ian; Frank, Eibe 2005. Data Mining: Practical Machine Learning Tools And Techniques. 2nd ed. Morgan Kaufmann Series in Data Management Systems. San Francisco, CA: Morgan Kaufmann.

Ene Vainik (Eesti Keele Instituut) on lõpetanud Tartu Ülikooli eesti keele ja kirjanduse erialal. Täiendanud ennast praktilise psühholoogia alal Professionaalse Psühholoogia Erakoolis. Magistri- (2001) ja doktorikraadi (2004) on kaitsnud üldkeeleteaduses Tartu Ülikooli juures. Uurimisobjektiks on eesti keele emotsioonisõnavara, selle struktuur, semantika ja varieerumine. Huvipakkuvateks teemadeks on ka psühholingvistika, kognitiivne semantika ja keele ning emotsioonide interaktsioon laiemalt. Ene.Vainik@eki.ee

Toomas Kirt (Küberneetika Instituut) kaitses 1999. a Tallinna Tehnikaülikoolis tehnikamagistri kraadi ja 2007. a doktorikraadi. Töötab TTÜ Küberneetika Instituudi foneetika ja kõnetehnoloogia laboratooriumis erakorralise teadurina. Uurimisteemadeks iseorganiseerumine, andmeanalüüs ja (tehis)intellekt.

Toomas.Kirt@mail.ee 


\section{HOW DO WE COMPREHEND THE CONCEPTS?}

\section{Ene Vainik, Toomas Kirt}

Institute of the Estonian Language,

Institute of Cybernetics at Tallinn Technical University

Scholars differ over the meaning of concept. Having first belonged to the field of logic and philosophy, concepts are now of interest also for (neuro)linguists, psychologists, cognitive scientists and and specialists in informatics. The aim of the article is to provide an overview of different theoretical approaches to concept and to demonstrate the relations of those approaches to certain tendencies in linguistic semantics.

In the classical approach it is held important that concepts should be defined in terms of necessary and sufficient conditions. In linguistics the approach based on very precise differentia has become the core of semantic component analysis, while its application has been central, e.g., in the field of terminology. Prototype theory, largely drawing on psychologial reliability, explains concepts as radial categories organized around the most representative members or category prototypes. For linguistics this approach implied that identification of the meanings of a word requires consideration of its typical as well as less typical uses alongside their different statuses. The theory theory aims at explaining the essence of concepts by means of certain more general knowledge structures (theories) that the concepts are part of. This approach has been used a lot for different semantic representations and description models of semantic content, such as frames, scripts or scenarios.

There have also been attempts to describe concepts in spatial terms, using dimensional representations. Cognitive linguistics, as well as cognitive sciences in general, are rather prone to construct some kind of semantic or conceptual spaces. Another type of concept explication is a network model of knowledge, which serves as basis for the so-called encyclopaedic approach to semantics. Here a concept is described by its relations with other concepts in the network of knowledge. The main linguistic applications are thesaurus dictionaries and electronic resources like WordNet. The dynamic approach views concepts as individual and variable situation-related processes going on in human brain, which have to do with processing and storing sensory data. It has been found that basically same parts of the neural substrate are involved in representing concepts (e. g. such as is represented by the verb grasp) as well as their underlying events (some act of grasping). Concepts are said to be simulations or reenactments of sensorimotor representations of events. That approach lays the basis for the so-called interactive semantics, arguing that human (incl. bodily) interaction with the external world is responsible for the development of the embodied concepts or schemes. Evolutionary approach sets out to reveal the mechanism of symbol grounding and concept formation, trying to explain it by ubiquitous loops of positive and negative feedback. It is vital for an organism, on the one hand, to tell hazardous situations from beneficial ones, and on the other hand, to assess what are the affordances of the situations. 
Instead of aiming at the one and only theory of what the concepts really are the article concludes that different theoretical approaches focus on different aspects of concepts. Description, explication and modelling of linguistic concepts are three different objectives, each thus preferring a different semantic representation.

Keywords: linguistics, semantics, epistemiology, cognitive science 